\title{
Perancangan Manajemen Electronic Filing System (E-Filing) Dengan Menggunakan Metode Alfred Di Kantor Desa Kuwaron, Grobogan
}

\author{
Ida Adha Kamilasari ${ }^{1}$, Paulus Hartanto ${ }^{2}$, Budi Hartono ${ }^{3}$ \\ ${ }^{1}$ Progdi Manajemen Informatika - Sekolah Tinggi Elektronika dan Komputer (STEKOM), \\ ida@gmail.com \\ ${ }^{2}$ Progdi Teknik Elektro - Sekolah Tinggi Elektronika dan Komputer (STEKOM), \\ Paulus@stekom.ac.id \\ ${ }^{3}$ Progdi Sistem Komputer - Sekolah Tinggi Elektronika dan Komputer (STEKOM), \\ budi@stekom.ac.id \\ Jl. Majapahit 605, Semarang, telp/fax : 024-6717201-02
}

\section{ARTICLE INFO}

Article history:

Received 19 Nov 2019

Received in revised form 23 Nov 2019

Accepted 25 Des 2019

Available online 25 Des 2019

\begin{abstract}
For this reason, the author makes the design of an electronic filing system (e-filing) management system, using the ALFRED method approach, namely: 1. Administrative Value (Value of use in administration), 2. Legal Value (Value of use in the field of law), 3. Fiscal Value (Use value in finance), 4.Research Value (Use value in the field of research), 5.Educational Value (Value use in education), 6.Documentative Value (Use value in the field of documentation). Making prototype application product Electronic Filing System (e-filing) management system uses Microsoft Visual Basic 6.0 software as a design media and as a programming language, and the SQL Server database as a storage media.

This research was conducted using the Research \& Development Method through a system design stage that was validated by experts and a prototype of a field-tested product involving users. The final result of this research is in the form of a prototype of an electronic filing system (e-filing) management system product that has been declared to function well so that it can produce information that is useful for the archiving process to the stage of making a report that can be done quickly and accurately in accordance with procedures that have been exist so as to make it easier to re-access archiving and provide public services with accurate and integrated information.

Keywords: Filing System, E-Filing, ALFRED method, R\&D method, Microsoft Visual Basic 6.0, SQL Server.
\end{abstract}

\section{Pendahuluan}

Perkembangan ilmu pengetahuan dan teknologi sudah digunakan di hampir semua bidang, baik itu instansi maupun institusi dan salah satunya adalah pada instansi Pemerintah. Informasi sangat dibutuhkan bagi kemajuan instansi dalam menjalankan tugasnya.

Rekaman informasi di instansi Pemerintah dapat dilihat dari keberadaan arsipnya. Sebenarnya arsip tidak pernah diciptakan secara khusus, akan tetapi arsip akan lahir apabila ada aktifitas didalam 
instansi, dengan demikian arsip akan menjadi bukti dokumenter atau sebagai alat pengingat sekaligus pengawas berbagai kegiatan instansi yang bersangkutan.

Kantor Desa Kuwaron yang merupakan instansi Pemerintah tingkat Kabupaten Grobogan yang berada di wilayah Kecamatan Gubug, beralamat di Desa Kuwaron Jalan Letjen R. Suprapto No.34, dalam melakukan penyimpanan dan pengelolaan pengarsipan masih manual sehingga ada data yang tidak tercatat dan hilang, pengarsipan surat masuk dan surat keluar juga ditulis dalam buku sebagai penyimpanan datanya sehingga ada data yang tidak tercatat dalam pengarsipan, kesulitan dalam pencarian datanya sehingga pelayanan menjadi lama, keterbatasan tempat penyimpanan dan waktu, sehingga suatu saat arsip dapat dimusnahkan sebelum waktunya.

Berikut adalah tabel rekapitulasi laporan kependudukan di Kantor Desa Kuwaron pada bulan Februari, Maret dan April 2014:

Tabel 1 Laporan Kependudukan Desa Kuwaron (Februari-April 2014)

\begin{tabular}{|c|l|c|c|c|c|c|c|}
\hline \multirow{2}{*}{ No } & \multirow{2}{*}{ Pendataan Arsip } & \multicolumn{2}{|c|}{ Februari 2014 } & \multicolumn{2}{c|}{ Maret 2014 } & \multicolumn{2}{|c|}{ April 2014 } \\
\cline { 3 - 8 } & & L & P & L & P & L & P \\
\hline 1 & Penduduk Bulan ini & 4293 & 4407 & 4295 & 4400 & 4291 & 4395 \\
\hline 2 & Lahir bulan ini & 9 & 4 & 1 & 2 & 5 & 4 \\
\hline 3 & Mati bulan ini & 2 & 2 & 3 & 4 & 2 & 2 \\
\hline 4 & Pendatang bulan ini & 4 & 4 & 5 & 0 & 0 & 1 \\
\hline 5 & Pindah bulan ini & 9 & 13 & 7 & 3 & 6 & 6 \\
\hline 6 & $\begin{array}{l}\text { Penduduk Akhir Bulan } \\
\text { ini }\end{array}$ & 4295 & 4400 & 4291 & 4395 & 4288 & 4392 \\
\hline
\end{tabular}

Berikut ini rekapitulasi mengenai surat pengantar kependudukan periode Februari - April 2014: Tabel 2 Surat Pengantar Kependudukan Desa Kuwaron

\begin{tabular}{|c|l|c|c|c|c|c|c|}
\hline No & \multicolumn{1}{|c|}{ Bulan } & Lahir & Mati & $\begin{array}{c}\text { Pemb. } \\
\text { KTP }\end{array}$ & Nikah & Pindah & Pendatang \\
\hline 1 & $\begin{array}{l}\text { Februari } \\
2014\end{array}$ & 13 & 4 & 20 & 10 & 22 & 8 \\
\hline 2 & Maret 2014 & 3 & 7 & 15 & 15 & 10 & 5 \\
\hline 3 & April 2014 & 9 & 4 & 18 & 5 & 12 & 1 \\
\hline & Total & $\mathbf{2 5}$ & $\mathbf{1 5}$ & $\mathbf{5 3}$ & $\mathbf{3 0}$ & $\mathbf{4 4}$ & $\mathbf{1 4}$ \\
\hline
\end{tabular}

E-FilingSystem pengarsipan adalah sistem informasi pencatatan surat-menyurat dan pengarsipan. Sistem ini mendukung prinsip Good Government dan Good Corporate Governance dalam mencapai efisiensi dan efektifitas pencapaian tujuan, baik untuk instansi Pemerintah maupun swasta.E-Filing membantu mengefektifkan kerapian pengarsipan surat dan dokumen-dokumen institusi, penugasan, dan distribusi pekerjaan terkait dengan isi surat bisa dilakukan dengan cepat dan real time.

Didasarkan dari temuan aktual tersebut, maka penulis mencoba untuk memberikan solusi dengan membangun sistem pengarsipan guna menunjang pekerjaan pengarsipan dan pengelolaan datanya. Sebagai alternatif untuk pemecahan dari masalah pengarsipan menggunakan metode ALFRED, yaitu : 1 . Administrative Value (Nilai guna di bidang administrasi), 2. Legal Value (Nilai guna di bidang hukum), 3.Fiscal Value (Nilai guna di bidang keuangan), 4.Research Value (Nilai guna di bidang penelitian), 5.Educational Value (Nilai guna di bidang pendidikan), 6.Documentative Value (Nilai guna di bidang dokumentasi).

Adanya rancang bangun ini diharapkan proses pengarsipan sampai pada tahap pembuatan laporan dapat dilakukan dengan cepat dan akurat sesuai dengan prosedur yang telah ada sehingga mempermudah mengakses kembali pengarsipan serta memberikan pelayanan masyarakat dengan informasi yang akurat dan terintegrasi.

\section{Landasan Teori}

Perancangan adalah merupakan kegiatan menentukan bentuk spesifik hasil akhir, bentuk, sifat, serta mendefinisikan penekanan atau karakter spesifik dari upaya perencanaan yang relevan dengan situasi, berapa banyak studi kelayakan. Sebelum masuk tahap perancangan sistem atau desain sistem, tahap yang harus dilalui terlebih dahulu adalah tahap analisis sistem. Analisis sistem didefinisikan sebagai bagaimana memahami dan menspesifikasi dengan detail apa yang harus dilakukan oleh sistem. Setelah tahap analisis, maka dilanjutkan dengan tahap perancangan atau desain sistem. Perancangan ini sendiri adalah proses

ELKOM Vol. 12, No. 2, Desember 2019: 22 - 33 
penerapan berbagai teknik dan prinsip yang bertujuan untuk mendefinisikan sebuah peralatan, satu proses atau satu sistem secara detail yang membolehkan dilakukan realisasi fisik. Sementara desain sistem diartikan sebagai menjelaskan dengan detail bagian-bagian dari sistem informasi yang akan diimplementasikan. Dengan demikian, analisis dan desain sistem (ANSI) bisa didefinisikan sebagai proses organisasional kompleks dimana sistem informasi berbasis komputer dapat diimplementasikan. (Hanif, 2007)

Sistem merupakan suatu usaha yang terdiri dari bagian-bagian yang berkaitan satu sama lain yang berusaha mencapai suatu tujuan dalam suatu lingkungan kompleks. (Marimin, 2009), Sistem didefinisikan sebagai suatu jaringan kerja dari prosedur-prosedur yang saling berhubungan, terkumpul bersama-sama untuk melakukan suatu kegiatan atau untuk tujuan tertentu. (Yakub, 2012)

Pengertian tersebut mencerminkan adanya beberapa bagian dan hubungan antarbagian, hal ini menunjukkan kompleksitas dari sistem yang meliputi kerjasama antara bagian yang interdependen satu sama lain. Selain itu, dapat dilihat bahwa sistem berusaha mencapai tujuan.Pencapaian tujuan ini menyebabkan timbulnya dinamika, perubahan yang terus-menerus perlu dikembangkan dan dikendalikan.

Menurut Fuad (2006) menjelaskan manajemen merupakan suatu proses yang melibatkan kegiatan perencanaan, pengorganisasian, pengarahan, dan pengendalian yang dilakukan untuk mencapai sasaran perusahaan melalui pemanfaatan sumber daya manusia dan sumber daya lainnya. Dari pengertian tersebut dijumpai adanya aktifitas-aktifitas khusus dalam manajemen yang merupakan suatu proses untuk mencapai sasaran-sasaran yang telah ditetapkan sebelumnya.

Dalam mencapai tujuannya, selain memanfaatkan sumber-sumber daya yang ada, manajemen juga menggunakan metode ilmiah dan seni dalam setiap pendekatan atau penyelesaian masalah-masalah yang dihadapi. Metode ilmiah yang digunakan umumnya meliputi kegiatan sebagai berikut :

a. Mengetahui adanya persoalan.

b. Mendefinisikan persoalan.

c. Mengumpulkan fakta, data, dan informasi.

d. Menyusun alternatif penyelesaian.

e. Mengambil keputusan dengan memilih salah satu alternatif penyelesaian.

f. Melaksanakan keputusan serta melakukan tindak lanjut.

E-Filing System pengarsipan adalah sistem informasi pencatatan surat-menyurat dan pengarsipan. Sistem ini mendukung prinsip Good Government dan Good Corporate Governance dalam mencapai efisiensi dan efektifitas pencapaian tujuan, baik untuk instansi Pemerintah maupun swasta.E-Filing membantu mengefektifkan kerapian pengarsipan surat dan dokumen-dokumen institusi, penugasan dan distribusi pekerjaan terkait dengan isi surat bisa dilakukan dengan cepat dan real time.

Microsoft Visual Basic 6.0 merupakan bahasa pemrograman yang cukup populer dan mudah untuk dipelajari, dapat membuat program dengan aplikasi GUI (Graphical User Interface) atau program yang memungkinkan pemakai komputer berkomunikasi dengan komputer tersebut dengan menggunakan modus grafik atau gambar.

Microsoft Visual Basic 6.0 menyediakan fasilitas yang memungkinkan untuk menyusun sebuah program dengan memasang objek-objek grafis dalam sebuah form. Selain itu Visual Basic juga menawarkan berbagai kemudahan dalam mengelola sebuah database.Kemudahan ini masih ditambah lagi dengan tersedianya sarana dan piranti yang lengkap.

SQL Server adalah sebuah RDBMS (Relational Database Management System) yang dikembangkan oleh Microsoft, yang digunakan untuk menyimpan dan mengolah data. Pada $S Q L$ Server, kita bisa melakukan pengambilan dan modifikasi data yang ada dengan cepat dan efisien. Pada $S Q L$ Server, kita bisa membuat objek-objek yang sering digunakan pada aplikasi bisnis, seperti membuat database,table, function, stored procedure, trigger, dan view. Selain objek, kita juga menjalankan perintah SQL(Structured Query Language) untuk mengambil data.(Fauzi, 2012)

Menurut Fajar (2010) metode ALFRED adalah suatu ukuran terhadap penilaian dari suatu arsip yang memiliki nilai guna masing-masing. Kegiatan ini dilakukan sebelum terjadinya pemindahan atau pemusnahan arsip. Kriteria penilaian arsip yang umum digunakan secara Internasional adalah dengan metode $A L F R E D$, yaitu :

A : Administrative Value (Nilai guna di bidang administrasi), misalnya nikah.

$\mathrm{L}$ : Legal Value (Nilai guna di bidang hukum), misalnya permohonan KK.

F : Fiscal Value (Nilai guna di bidang keuangan), misalnya pembuatan KTP.

$\mathrm{R}$ : Research Value (Nilai guna di bidang penelitian), misalnya kelahiran penduduk dan kematian penduduk. 
E : Educational Value (Nilai guna di bidang pendidikan), misalnya demografi (kependudukan).

D : Documentative Value (Nilai guna di bidang dokumentasi), misalnya, kepindahan penduduk dan kedatangan penduduk.

Metode penelitian dan pengembangan (Research and Development) merupakan penelitian yang digunakan untuk menghasilkan produk tertentu dan menguji keefektifan produk tersebut. (Sugiyono, 2011)

Adapun langkah-langkah penelitian dan pengembangan ada sepuluh langkah, sebagai berikut : (1) Potensi dan masalah, (2) Pengumpulan data, (3) Desain produk, (4) Validasi desain, (5) Revisi desain, (6) Ujicoba produk, (7) Revisi produk, (8) Ujicoba pemakaian, (9) Revisi produk, dan (10) Produksi massal.

\section{Metodologi}

Model pengembangan yang dilakukan dalam skripsi ini adalah menggunakan model Penelitian Pengembangan (R\&D) dengan 6 tahapan Metode $R \& D$ Borg and Gall yaitu :

a. Tahap Awal : permasalahan pokok yang dicari solusinya adalah belum adanya sistem yang dapat membantu petugas kelurahan dalam mengambil suatu keputusan untuk membantu dalam pengarsipan.

b. Pengumpulan Data

1) Mengamati secara langsung sistem kerja pada Dinas Kelurahan Kuwaron.

2) Melakukan wawancara dengan pimpinan Dinas Kelurahan Kuwaron.

3) Melakukan study literaturedari berbagai sumber untuk membangun sistem, sehingga sistem yang dihasilkan memenuhi semua kebutuhan pemakai.

c. Desain Produk : flowchart,Data Flow Diagram (DFD), Basis Data, Entity Relational Diagram(ERD), Normalisasi, tampilan input dan output dan Desain Arsitektur.Hasil akhir ini berupa desain produk yang baru yang dilengkapi dengan spesifikasinya.

d. Validasi Desain : uji validasi ini dinilai oleh pakar dari STEKOM (pakar kompeten) untuk menilai apakah rancangan produk yang baru lebih valid dari yang lama atau tidak.

e. Revisi Desain : dilakukan untuk memperbaiki desain produk yang dibuat sampai desain dinyatakan valid oleh pakar.

f. Ujicoba Produk : setelah desain dinyatakan valid, dilakukan pembuatan source code program aplikasi menjadi prototype produk sistem kemudian di uji oleh pengguna/useruntuk membandingkan efektifitas dan efisiensi sistem kerja pada sistem lama dengan sistem baru serta dapat memanfaatkan sistem untuk melihat informasi pengarsipan.

g. Melalui penelitian dalam skala kecil ini penulis mempunyai tujuan yaitu metode penelitian yang digunakan untuk menghasilkan produk tertentu, dan menguji keefektifan produk tersebut.

\section{Hasil dan Pembahasan}

\section{a. Form Login}

Form login berfungsi untuk masuk ke dalam sistem. Sistem akan mengidentifikasi pengguna yang berhak atau tidak berhak untuk mengakses sistem dengan memverifikasi username dan password pengguna, serta untuk memilah sesuai hak aksesnya.

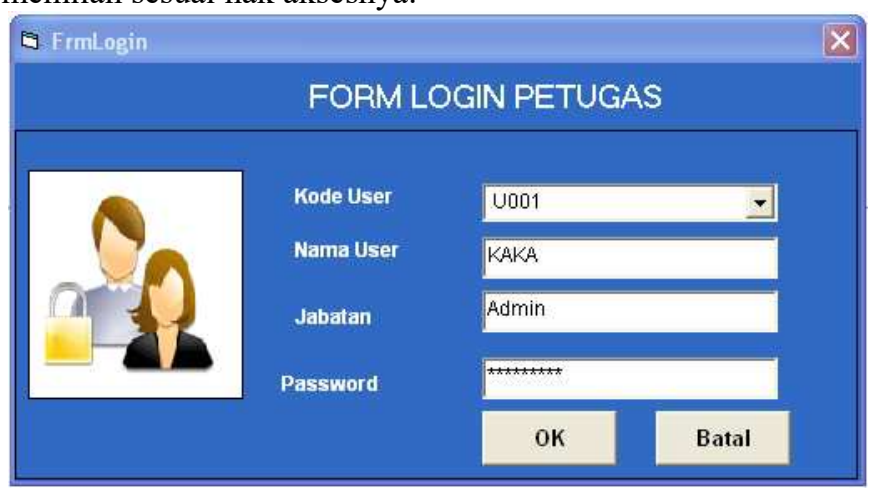

Gambar 1 Form Login

Keterangan Form:

Kode User di isi dengan = admin, kades/lurah, kasi pemerintah, dan sekretaris desa (sesuai dengan jabatan).

b. Form Kelahiran

Fungsi : Untuk menginputkan, simpan, edit dan hapus data kelahiran.

ELKOM Vol. 12, No. 2, Desember 2019 : 22 - 33 


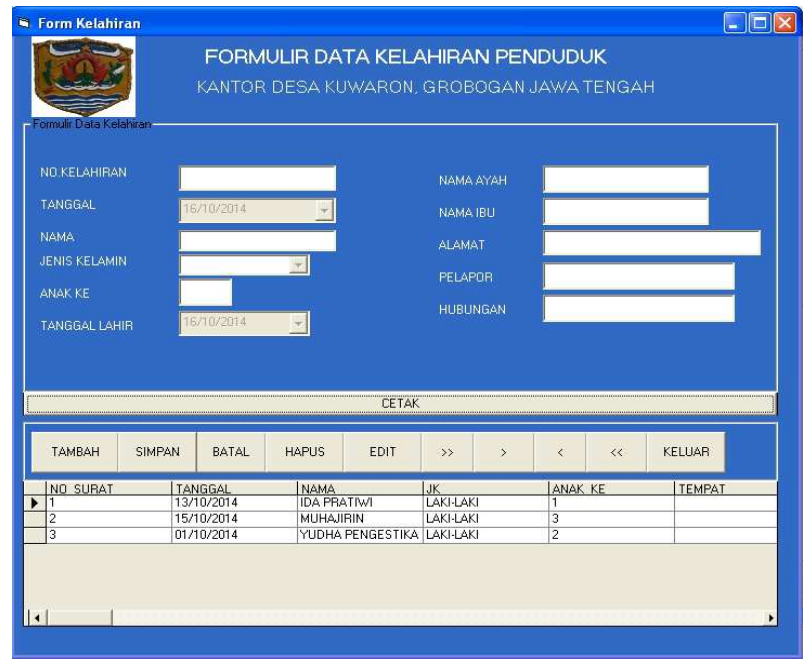

Gambar 2 Form Kelahiran

Keterangan Form:

\begin{tabular}{|l|l|}
\multicolumn{1}{|c|}{ Komponen } & \multicolumn{1}{c|}{ Tabel 3 Keterangan Form Kelahiran } \\
\hline No kelahiran & Untuk input nomor kelahiran (format 5digit : L9999) \\
\hline Tanggal & Untuk input data (DD-MM-YYYY) \\
\hline Nama & Untuk input nama bayi lahir maksimal 50 karakter \\
\hline Jenis Kelamin & Combo berisi pilihan jenis kelamin \\
\hline Anak Ke & Untuk input urutan anak dalam keluarga \\
\hline Tanggal lahir & Untuk input tanggal lahir (DD-MM-YYYY) \\
\hline Ayah & Untuk input nama ayah \\
\hline Ibu & Untuk input nama Ibu \\
\hline Alamat & Untuk input alamat \\
\hline Pelapor & Untuk input nama pelapor \\
\hline Hubungan & Untuk input hubungan pelapor dengan bayi \\
\hline
\end{tabular}

c. Form Kematian Penduduk

Fungsi : Untuk menginputkan, simpan, edit dan hapus data kematian.

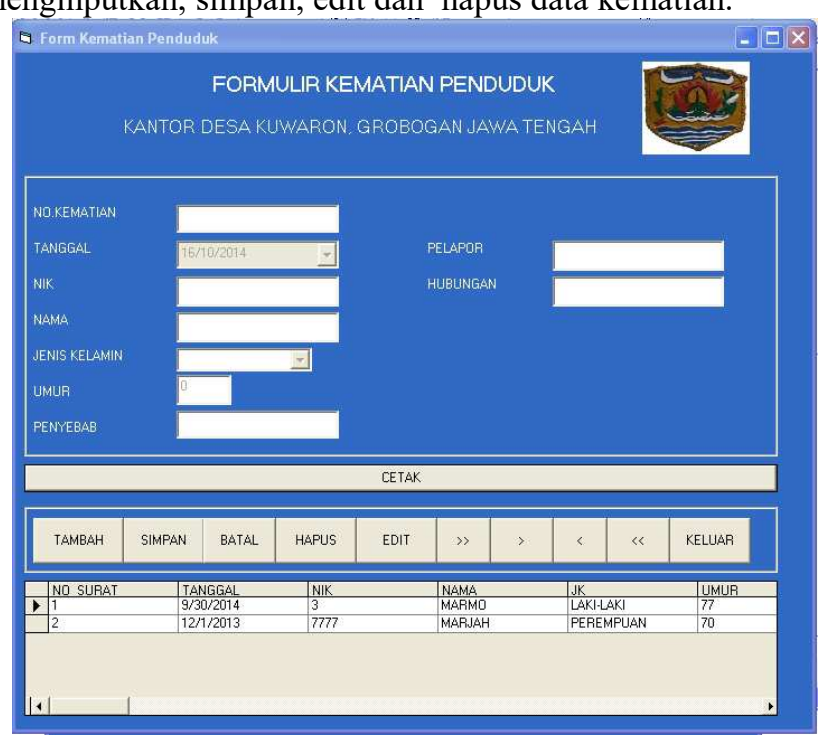

Gambar 3 Form Kematian Penduduk

Keterangan Form:

Perancangan Manajemen Electronic Filing System (E-Filing) Dengan Menggunakan Metode Alfred Di Kantor Desa Kuwaron, Grobogan (Ida Adha Kamilasari) 


\begin{tabular}{|c|c|}
\hline \multicolumn{2}{|r|}{ Tabel 4 Keterangan Form Kematian } \\
\hline Komponen & Keterangan \\
\hline No kematian & Untuk input nomor kematian (format 5digit : M9999) \\
\hline Tanggal & Untuk input tanggal meninggal (DD-MM-YYYY) \\
\hline NIK & Untuk input nomor penduduk (NIK terdiri dari 16 digit) \\
\hline Nama & Untuk input nama bayi meninggal maksimal 50 karakter \\
\hline Jenis Kelamin & Combo berisi pilihan jenis kelamin \\
\hline Umur & Untuk Input data umur \\
\hline Penyebab & Untuk input penyebab meninggal \\
\hline Pelapor & Untuk input nama pelapor \\
\hline Hubungan & Untuk input hubungan pelapor dengan bayi \\
\hline
\end{tabular}

\section{d. Form Kedatangan Penduduk}

Fungsi : Untuk menginputkan, simpan, edit dan hapus data kedatangan penduduk baru.

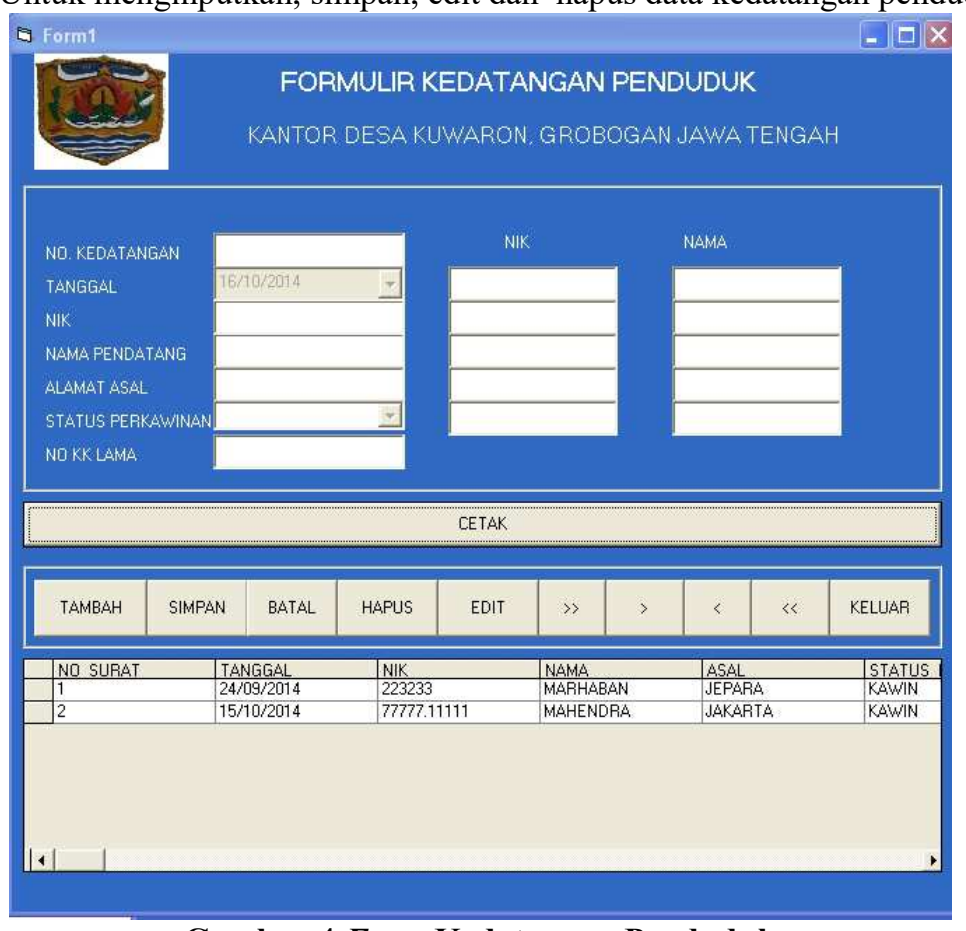

Gambar 4 Form Kedatangan Penduduk

Keterangan Form :

Tabel 5 Keterangan Form Kedatangan Penduduk

\begin{tabular}{|l|l|}
\hline \multicolumn{1}{|c|}{ Komponen } & \multicolumn{1}{c|}{ Keterangan } \\
\hline No kedatangan & Untuk input nomor kedatangan (format 7digit) \\
\hline Tanggal & Untuk input tanggal kedatangan (DD-MM-YYYY) \\
\hline NIK & Untuk input nomor penduduk (NIK terdiri dari 16 digit) \\
\hline Nama Pendatang & Untuk input nama pendatang 50 karakter \\
\hline Alamat asal & Untuk input alamat asal \\
\hline Status perkawinan & Combo berisi pilihan status perkawinan \\
\hline No KK & Untuk input nomor KK lama \\
\hline
\end{tabular}

\section{e. Form Kepindahan Penduduk}

Fungsi : Untuk menginputkan, simpan, edit dan hapus data kepindahan penduduk keluar.

ELKOM Vol. 12, No. 2, Desember 2019: $22-33$ 
27

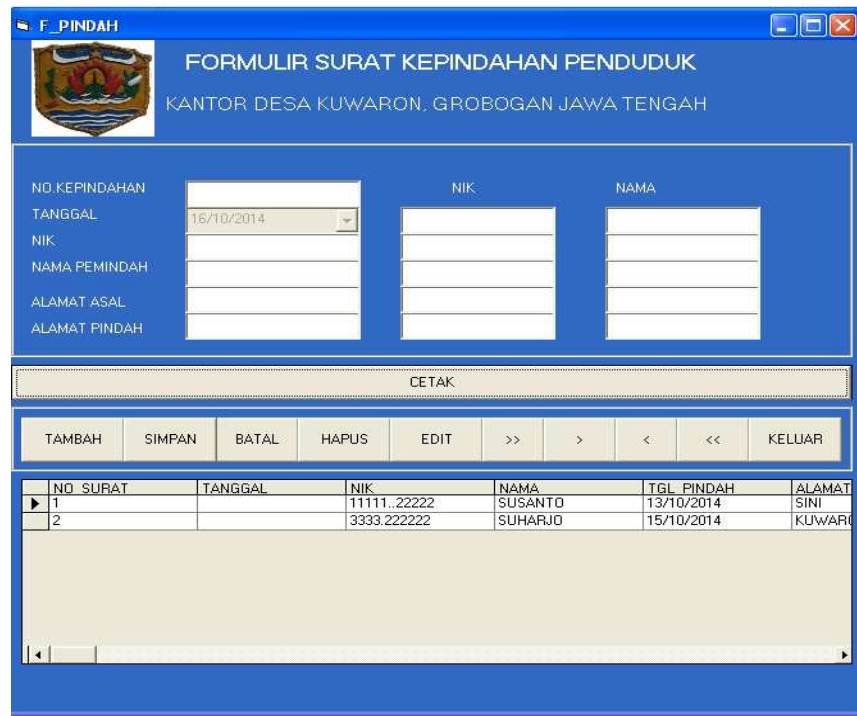

Gambar 6 Form Kepindahan Penduduk

Keterangan Form:

Tabel 7 Keterangan Form Kepindahan Penduduk

\begin{tabular}{|l|l|}
\hline \multicolumn{1}{|c|}{ Komponen } & \multicolumn{1}{c|}{ Keterangan } \\
\hline No kepindahan & Untuk input nomor kepindahan (format 7digit) \\
\hline Tanggal & Untuk input tanggal kedatangan (DD-MM-YYYY) \\
\hline NIK & Untuk input nomor penduduk (NIK terdiri dari 16 digit) \\
\hline Nama Pemindah & Untuk input nama pemindah 50 karakter \\
\hline Alamat asal & Untuk input alamat asal \\
\hline Alamat pindah & Untuk input alamat tujuan \\
\hline
\end{tabular}

\section{f. Form Permohonan KTP}

Fungsi : Untuk menginputkan, simpan, edit dan hapus data permohonan KTP.

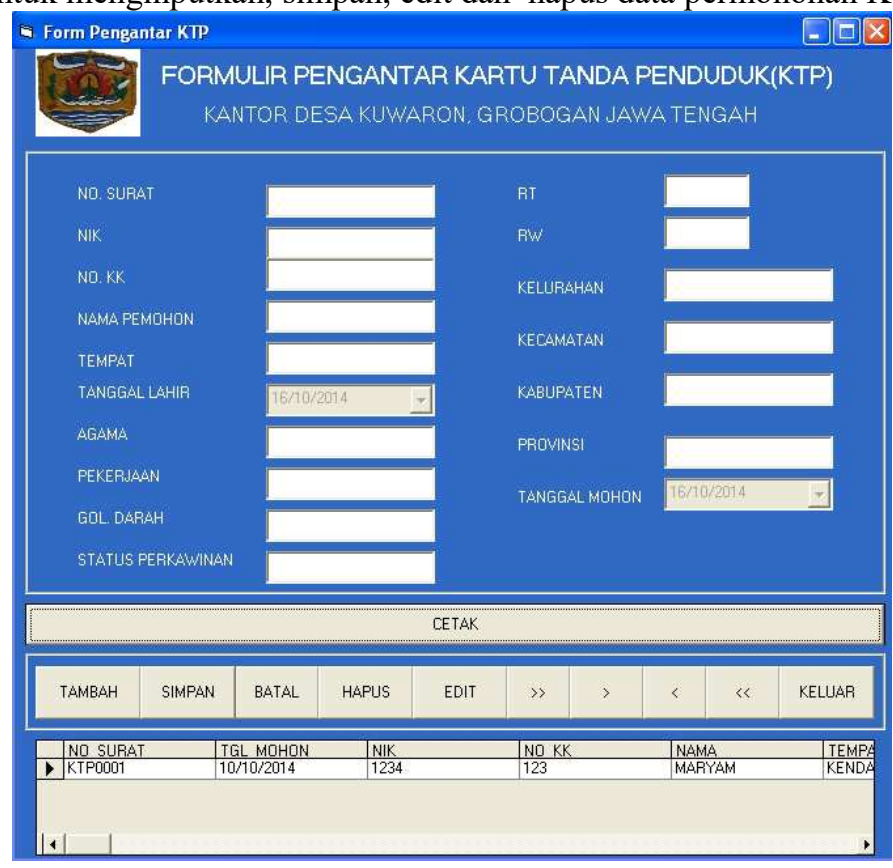

Gambar 7 Form Permohonan KTP

Perancangan Manajemen Electronic Filing System (E-Filing) Dengan Menggunakan Metode Alfred Di Kantor Desa Kuwaron, Grobogan (Ida Adha Kamilasari) 
Keterangan Form:

Tabel 8 Keterangan Form Permohonan KTP

\begin{tabular}{|l|l|}
\hline \multicolumn{1}{|c|}{ Komponen } & \multicolumn{1}{c|}{ Keterangan } \\
\hline No Surat & Untuk input nomor surat (format 7digit) \\
\hline No KK & Untuk input nomor KK (NKK terdiri dari 16 digit) \\
\hline NIK & Untuk input nomor penduduk (NIK terdiri dari 16 digit) \\
\hline Nama Pemohon & Untuk input nama pemohon KTP (maks 50 karakter) \\
\hline Tempat & Untuk input nama kota kelahiran \\
\hline Tanggal Lahir & Untuk input tanggal kelahiran \\
\hline Agama & Untuk input agama pemohon \\
\hline Pekerjaan & Untuk input pekerjaan pemohon \\
\hline Gol darah & Untuk input gol darah \\
\hline Status Perkawinan & Combo berisi pilihan status perkawinan \\
\hline RT & Untuk input RT \\
\hline RW & Untuk input RW \\
\hline Kelurahan & Untuk input nama Kelurahan \\
\hline Kecamatan & Untuk input nama Kecamatan \\
\hline Kabupaten & Untuk input nama Kabupaten \\
\hline Provinsi & Untuk input nama Provinsi \\
\hline Tanggal Mohon & Untuk input data tanggal permohonan \\
\hline
\end{tabular}

\section{g. Form Permohonan KK}

Fungsi : Untuk menginputkan, simpan, edit dan hapus data permohonan KK.

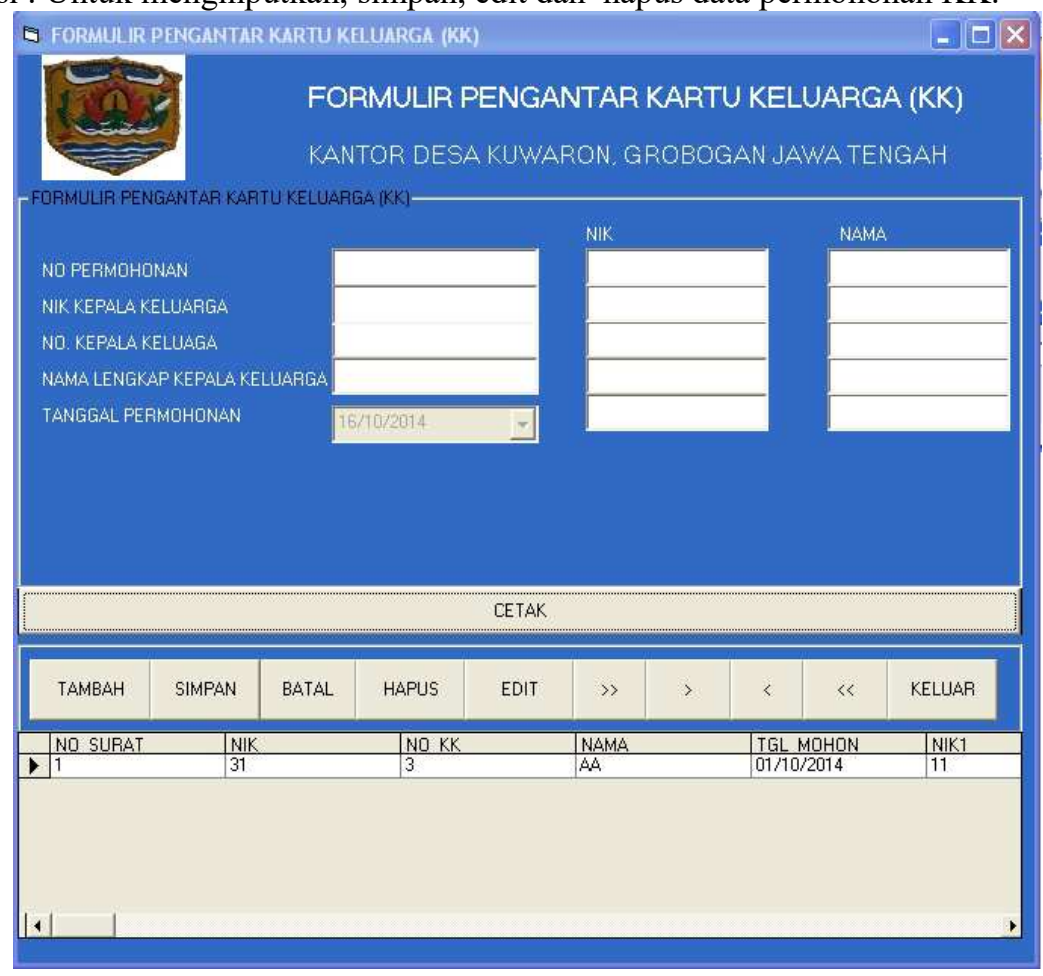

Gambar 8 Form Permohonan KK

Keterangan form :

Tabel 9 Keterangan Form permohonan Kartu keluarga

\begin{tabular}{|l|l|}
\hline \multicolumn{1}{|c|}{ Komponen } & \multicolumn{1}{c|}{ Keterangan } \\
\hline No Permohonan & Untuk input nomor permohonan (format 6digit) \\
\hline NIK Kepala Keluarga & Untuk input nomor NIK kepala keluarga (16 digit) \\
\hline No KK Kepala keluarga & $\begin{array}{l}\text { Untuk input nomor KK kepala keluarga (NKK terdiri dari 16 } \\
\text { digit) }\end{array}$ \\
\hline
\end{tabular}

ELKOM Vol. 12, No. 2, Desember 2019: 22 - 33 
29

\begin{tabular}{|l|l|}
\hline $\begin{array}{l}\text { Nama Lengkap Kepala } \\
\text { Keluarga }\end{array}$ & Untuk input nama kepala keluarga \\
\hline Tanggal Permohonan & Untuk input data tanggal permohonan \\
\hline
\end{tabular}

h. Form Surat Keluar

Fungsi : Untuk menginputkan, simpan, edit dan hapus data Surat Keluar.

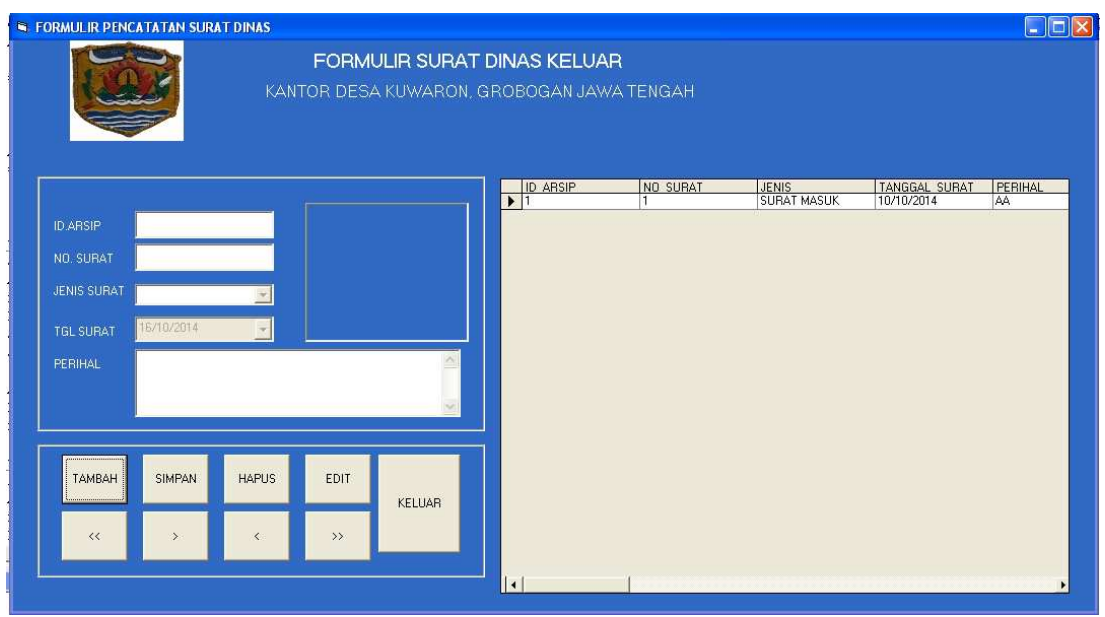

Gambar 9 Form Surat Keluar

Keterangan Form :

Tabel 10 Keterangan Form Surat Keluar

\begin{tabular}{|l|l|}
\hline \multicolumn{1}{|c|}{ Komponen } & \multicolumn{1}{c|}{ Keterangan } \\
\hline Id_arsip & Untuk input id arsip (format 6 digit) \\
\hline No Surat & Untuk input nomor surat \\
\hline Jenis Surat & Combo berisi pilihan jenis surat \\
\hline Tanggal Surat & Untuk input data tanggal surat \\
\hline Perihal & Untuk input perihal surat keluar \\
\hline Upload & Untuk upload berkas file surat keluar \\
\hline
\end{tabular}

i. Form Surat Masuk

Fungsi : Untuk menginputkan, simpan, edit dan hapus data Surat Masuk.

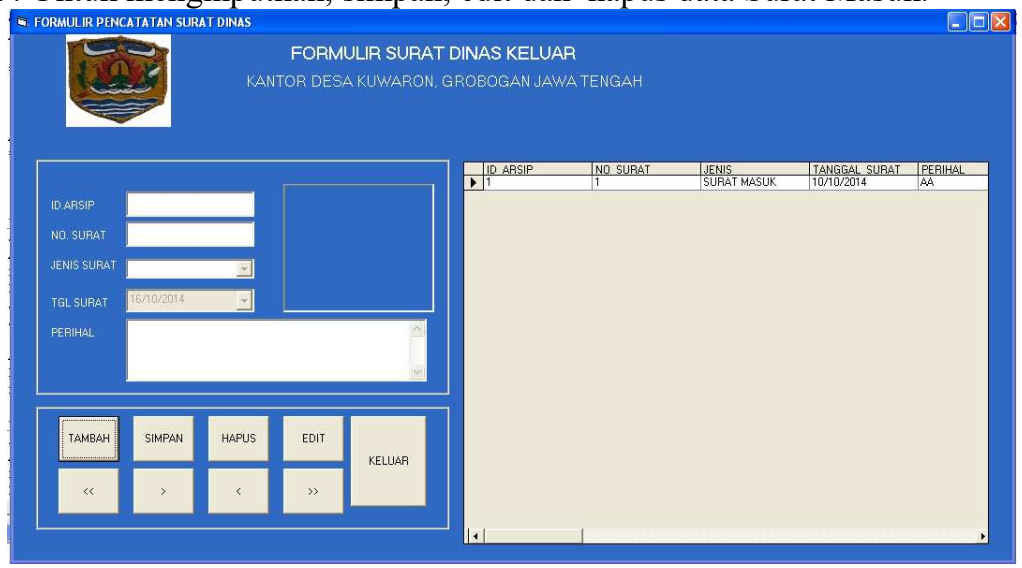

Gambar 10 Form Surat Masuk

Keterangan Form:

Tabel 11 Keterangan Form Surat Masuk

\begin{tabular}{|l|l|}
\hline \multicolumn{1}{|c|}{ Komponen } & \multicolumn{1}{c|}{ Keterangan } \\
\hline Id_arsip & Untuk input id arsip (format 6 digit) \\
\hline No Surat & Untuk input nomor surat \\
\hline Jenis Surat & Combo berisi pilihan jenis surat \\
\hline Tanggal Surat & Untuk input data tanggal surat \\
\hline
\end{tabular}

Perancangan Manajemen Electronic Filing System (E-Filing) Dengan Menggunakan Metode Alfred Di Kantor Desa Kuwaron, Grobogan (Ida Adha Kamilasari) 


\begin{tabular}{|l|l|}
\hline \hline Perihal & Untuk input perihal surat masuk \\
\hline Upload & Untuk upload berkas file surat masuk \\
\hline
\end{tabular}

j. Laporan Data Kelahiran

Fungsi : Untuk menampilkan data kelahiran penduduk.

$17 / 10 / 2014$

LAPORAN KELAHIRAN PENDUDUK

KANTOR DESA KUW ARON, GROBOGAN JAWA TENGAH

NO_SURAT 1

TANGGAL 13/10/2014

\begin{tabular}{llcllllll} 
NAMA & JK & ANAK_KE & TGLLAHIR & AYAH & IBU & ALAMAT & PELAPOR & HUB_PEL \\
\hline IDA PRATI & LAKI-LAKI & 1 & $13 / 10 / 2014$ & SARWO & LILI & SAHA & AS & SAUDARA
\end{tabular}

NO_SURAT 2

TANGGAL 15:10/2014

\begin{tabular}{llcllllll} 
NAMA & JK & ANAK_KE & TGLLAHIR & AYAH & IBU & ALAMAT & PELAPOR & HUB_PEL \\
\hline MUHAJIRI & LAKI-LAKI & 3 & $15 / 10 / 2014$ & FARMO & HIDAYAH & DESA KUW ANDI & KEPONAK
\end{tabular}

\section{Gambar 17 Eaporan Kelahiran}

Keterangan :

Form di atas menampilkan laporan kelahiran penduduk di Kantor Desa Kuwaron, Grobogan pada bulan oktober.

k. Laporan Data Kedatangan

Fungsi: Untuk menamnilkan data kedatangan nenduduk baru

$17 / 10 / 2014$

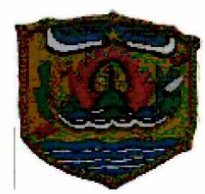

LAPORAN KEDATANGAN PENDUDUK

KANTOR DESA KUWARON, GROBOGAN JA WA TENGAH

NO_SURAT

TANGGAL $\quad 2409 / 2014$

NIK 223233

NAMA ASAL STATUS_ NO_KKLAMA NIK NAMA

$\begin{array}{lllll}\text { MARHABAN TEPARA } & \text { KAWIN } & 1221212 & 1111 & \text { RIKA }\end{array}$

2222 MARCO

3333 BUDI

Gambar 12 Eaporan Kedatangan Penduduk

Keterangan :

ELKOM Vol. 12, No. 2, Desember 2019: 22 - 33 
31

Form di atas menampilkan laporan kedatangan penduduk di Kantor Desa Kuwaron, Grobogan pada bulan september.

1. Laporan Surat Dinas

Fungsi-Untuk menamnilkan lanoran keluar masuknva surat dinas

171102014

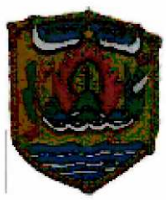

LAPORAN SURAT DINAS

KANTOR DESA KUWARON, GROBOGAN, JAWA TENGAH

\begin{tabular}{|c|c|c|c|c|}
\hline ID_AR SIP & NO_SURAT & JEMS & TANGG & PERIHAL \\
\hline 1 & 1 & SURAT MASUK & $10 / 10 / 2014$ & PENYULUHAN PETANI \\
\hline
\end{tabular}

Keterangan :

Gambar 13 Laporan Surat Dinas

Form di atas menampilkan laporan surat dinas di Kantor Desa Kuwaron, Grobogan pada bulan oktober.

m. Laporan Surat Permohonan Kartu Keluarga

Fungsi : Untuk menampilkan laporan surat permohonan Kartu Keluarga.

$17110 / 2014$

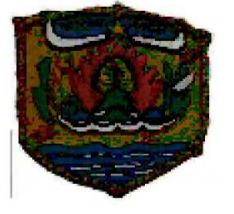

SURAT PERMOHAHAN KARTU KELUARGA

KANTOR DESA KUWARON, GROBOGAN, JAWA ENGAH

$\begin{array}{lc}\text { NO_SURAT } & 12 \\ \text { NIK } & 313433\end{array}$

NO_KK NAMA

323333 SUNHADI

$\begin{array}{cl}\text { TGL_MOHON } & \text { NIKl } \\ 01 / 10 / 2014 & 1155555\end{array}$

NAMA

R.AMLI

\section{Gambar 14 Laporan Surat Permohonan Kartu Keluarga}

Keterangan :

Form di atas menampilkan laporan surat permohonan kartu keluarga di Kantor Desa Kuwaron, Grobogan pada bulan oktober. 


\section{n. Laporan Surat Pengantar KTP}

Fungsi : Untuk menamnilkan laporan surat nengantar nembuatan KTP

171002014

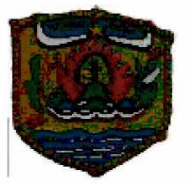

LAPORAN KARTU TANDA FEHDUDUK

KANTOR DESA KUWARON, ROBOGAH, JA WA TENGA

NO_SURAT TGL NAMA

KTPO001

10110) MARYAM

A

KELURAHAN

Gambar 15 Laporan Surat Pengantar KYP

Keterangan :

Form di atas menampilkan laporan surat pengantar KTP di Kantor Desa Kuwaron, Grobogan pada bulan oktober.

\section{Kesimpulan}

Sistem lama dalam pengarsipan surat masuk dan surat keluar dalam melakukan penyimpanan dan pengelolaan pengarsipan masih manual sehingga ada data yang tidak tercatat dan hilang, pengarsipan surat masuk dan surat keluar juga ditulis dalam buku sebagai penyimpanan datanya sehingga ada data yang tidak tercatat dalam pengarsipan, kesulitan dalam pencarian datanya sehingga pelayanan menjadi lama, keterbatasan tempat penyimpanan dan waktu, sehingga suatu saat arsip dapat dimusnahkan sebelum waktunya.

Setelah dibangun sistem baru dengan metode Alfred yang telah melalui beberapa tahapan pengujian yaitu pengujian desain (validasi desain) oleh pakar dan uji coba prototype produk aplikasi oleh user, maka prototype produk sistem manajemen electronic filing system (e-filing) yang telah selesai dibuat dinyatakan bisa berfungsi dengan baik sehingga telah dapat memberikan solusi untuk pengelolaan data penduduk dan pengarsipan seperti berikut ini :

a. E-Filing System pengarsipan dapat membantu mengefektifkan kerapian pengarsipan surat dan dokumen-dokumen, penugasan dan distribusi terkait dengan isi surat bisa dilakukan dengan cepat dan real time sehingga kesalahan dan kehilangan data dapat diminimalisir.

b. Manajemen Electronic Filing System (E-Filing) layak digunakan di Kantor Desa Kuwaron agar proses pengarsipan surat masuk dan surat keluar sampai pada tahap pembuatan laporan dapat dilakukan dengan cepat dan akurat sesuai dengan prosedur yang telah ada sehingga mempermudah mengakses kembali data yang diperlukan.

\section{Daftar Pustaka}

Andi Kristanto. 2008,Perancangan Sistem Informasi, Yogyakarta: Gavamedia.

Ema Utami. 2009,Konsep Dasar Pengolahan dan Pemrograman Database dengan SQLServer, Access dan Ms. Visual Basic, Yogyakarta: AndiOffset.

Fatah, H. A. 2007,Analisis dan Perancangan Sistem Informasi untuk Keunggulan Bersaing Perusahaan dan Organisasi Modern, Yogyakarta: AndiOffset.

Fauzi, Miftahul Amin. 2012,Pemrograman Database Visual basic 6 dan SQL Server 2000, Yogyakarta: AndiOffset.

Fuad, M. 2006,Pengantar Bisnis, Bogor: Grafika Mardi Yuana.

Indriyana, I, dkk. 2009,Membuat Sistem Informasi Penjualan Retail dengan SQL Server, Elex Media Komputindo, Jakarta.

Jogiyanto, H. 2009,Analisis dan Desain Sistem Informasi: Pendekatan Terstuktur Teori dan Praktek Aplikasi Bisnis, Yogyakarta: AndiOffset.

Kawan Pustaka. 2008, Fokus menyelesaikan soal-soal ujian, Jakarta: Kawan Pustaka.

ELKOM Vol. 12, No. 2, Desember 2019: 22 - 33 
33

Marimin, H. T. 2009,Sistem Informasi Manajemen Sumber Daya Manusia, Jakarta: Grasindo.

Naranthaka, B. 2010, Jaminan Kepastian hukum e-Filing Terhadap Pelaporan SPT dalam Sistem Administrasi Perpajakan di Indonesia, Surakarta: Skipsi.

Novarina, A. I. 2005,Implementasi Electronic Filling System (E-Filing) dalam Praktik Penyampaian Surat Pemberitahuan (SPT) di Indonesia, Semarang: Tesis.

Nuraida, I. 2008,Manajemen Administrasi Perkantoran, Yogyakarta: Kanisius.

Riyanto. 2009,Migrasi Microsoft SQL Server dengan Postgre SQL, Elex Media Komputindo, Jakarta.

Sugiyono. 2011,Metode Penelitian Kuantitatif Kualitatif dan R\&D, Bandung: Alfabeta.

Sutabri, T. 2012,Analisis Sistem Informasi, Yogyakarta: CV. Andi Offset.

Tet Padova. 2009, PDF Forms Using Acroba, Canada: Wiley Publishing.

Undang - Undang Nomor 43 Tahun 2009 tentang Kearsipan, Jakarta : ANRI.

Untoro, J. 2011,Target Nilai Rapor 10 Kupas Habis Semua Pelajaran SMP/MTS Kelas VII,Jakarta : PT. Wahyumedia.

Wati, N. F. 2010,Sistem Penyusutan Arsip Statis di Bidang Perpustakaan dan Kearsipan Daerah Provinsi Jawa Barat, Jurnal UNIKOM.

Yakub. 2012, Pengantar Sistem informasi, Yogyakarta: Graha Ilmu. 